\title{
Some Effects of Freezing in the Leaf, and of Citrate in vitro, on the Infectivity of a Tobacco Necrosis Virus
}

\author{
By F. C. BAWDEN and N. W. PIRIE \\ Rothamsted Experimental Station, Harpenden, Hertfordshire
}

SUMMARY: Preparations of the Rothamsted tobacco necrosis virus made from tobacco leaves that have been frozen while intact are less infective than preparations made from unfrozen leaves. Freezing minced leaves or expressed sap does not destroy infectivity. The suggestion is made that much virus in the intact leaf becomes infective only by means of a mechanism that is set in action by mincing and is disordered by freezing.

The infectivity, but not the serological activity, of the virus is lost on exposure to $0.02-0.01 \mathrm{M}$ neutral citrate; the extent of this inactivation is influenced by the temperature, pH, duration of exposure, concentration of virus and presence of salts and other substances. Similar processes could influence the infectivity of the virus in sap and may do so in the leaf.

The sensitivity of the Rothamsted culture of a tobacco necrosis virus towards changes in the composition of the fluid in which it is dissolved separates it sharply from tomato bushy stunt or tobacco mosaic viruses. In fluids having compositions comparable to those derived from macerated leaves, differences in infectivity with the last two viruses are usually attributed to the presence of varying amounts of substances that interfere with the normal processes of infection. Such inhibitors have no permanent effects on the viruses, which regain their initial infectivity when the substances are removed. By contrast, the infectivity of the Rothamsted tobacco necrosis virus can be increased or decreased by exposure to environments that appear not to influence the infectivity of the other two. In particular, infectivity does not remain constant when the virus is in the sap obtained by mincing and lightly pressing infected tobacco leaves. The differences persist through subsequent stages of isolation and the infectivity of a purified preparation depends on the physiological state of the plants from which it came and on the method of preparation used (Bawden \& Pirie, 1950).

The Rothamsted tobacco necrosis virus loses infectivity when exposed to some substances with low molecular weight. In an attempt to avoid exposing it to the low molecular weight components of sap, we subjected infected leaves to various treatments that liberate these components but not the virus. Although these treatments were innocuous to the isolated virus, or to the virus in minced leaves, when applied to intact leaves they decreased the infectivity, or the total yield, or both. This paper describes treatments that inactivate virus in the leaves and some of the variables that influence the inactivation of the isolated virus. The results of these experiments show that so many factors can affect the infectivity of this virus that we seem, in effects of this type, to have a partial explanation of the wide variations found in the properties of different preparations of the virus. There is no evidence about the 
state in which the virus occurs in infected cells, nor is there evidence that the actual phenomena described have any significance in the processes of infection and virus multiplication. The object of this paper is to direct attention to phenomena that may play a part in these processes, and also perhaps help to determine the resistance of plants to viruses, in the hope that later work may uncover the precise mechanisms involved.

\section{MATERIALS AND METHODS}

The virus was propagated in tobacco plants (Nicotiana tabacum var. White Burley), raised under low light intensity and placed in darkness for 1-2 days before they were inoculated. The leaves were lightly dusted with celite before being rubbed with infective sap. Leaves were picked from 5 to 8 days after being rubbed, before the lesions had coalesced and caused the tissue to dry unduly, and were minced by passage through a domestic meat mincer.

Virus was isolated from clarified sap by ultracentrifugation as already described (Bawden \& Pirie, 1950). Unless otherwise stated, the virus in sap was concentrated by freezing or the sap was allowed to stand at $3^{\circ}$ for 2 days before the first ultracentrifugation. The purified virus preparations were kept in water at about pH 6, an environment in which infectivity changed little during 1-2 weeks' storage at $3^{\circ}$. However, other changes did occur and these may cause some of the variability of our results.

Antisera were prepared by intravenous injections of purified virus into rabbits, and precipitin tests were made by adding $1 \mathrm{ml}$. of virus preparations at various dilutions to each of a series of tubes containing $1 \mathrm{ml}$. of antiserum at 1/50. Precipitin titres were taken as the greatest dilution, or, when purified material was used, the smallest concentration, of antigen to give a precipitate visible to the eye after $8 \mathrm{hr}$. incubation in a water-bath at $50^{\circ}$. Serial dilutions were usually made with a factor of two, but by observing precipitation at intervals and judging from the time taken for precipitation to occur at different dilutions and from the size of the precipitates, differences of less than this factor were estimated with fair accuracy.

Infectivity tests were made on French bean, Phaseolus vulgaris var. Prince, using the first formed leaves. Usually six or four inocula were compared together in any one test, and the different inocula were distributed over halfleaves selected so that each occurred an equal number of times on left- and right-hand halves and all pairs occurred on the same number of leaves. Tests were made at two dilutions of inoculum, usually varying by a factor of ten, and there were at least six replications at each dilution. The variations between the results of experiments made at different times are not thought to result from errors in infectivity tests. When the same experiment has been repeated after a short interval, reproducible results have been obtained. Variations occurred mainly when comparing effects of similar treatments on different preparations of the virus. As the susceptibility of bean leaves is enhanced by placing the plants in darkness before they are inoculated (Bawden \& Roberts, $1947,1948)$, it seemed possible that some variations might arise from making assays for infectivity at different times of the day. Control experiments, 
however, excluded this as an important factor, for although the total number of lesions produced by a given inoculum was affected, there was no appreciable effect on the relative numbers produced by different inocula. Other experiments also showed that no appreciable variability arose within a few hours from differences in time that elapsed between making test dilutions and applying the inocula to bean leaves. The time at which lesions are counted is of some importance when the inocula being compared produce widely different numbers. In the interval between the earliest and latest times at which lesions can be counted at all accurately, leaves with few lesions produce proportionally more additional ones than leaves with many. The effect is too small to explain variations observed between experiments with different virus preparations, but it was avoided, as far as possible, by delaying counting until the first-formed lesions began to spread along the veins.

\section{EXPERIMENTAL}

\section{Inactivation by treatments applied to the intact leaf}

Variations in the composition of leaf extracts may influence the number of lesions produced by a given quantity of infective virus. To diminish this source of error, in all experiments with virus from variously treated leaves, the extracts were ultracentrifuged and the pellet, resuspended in water, was used for comparative infectivity tests. In the type of centrifuge used (Masket, 1941), much of the pellet may redissolve in the bottom $0.5 \mathrm{ml}$. of supernatant fluid, particularly if the virus content is small or the extracts have been subjected to any pre-treatments that reduce the amount of sedimentable material. After centrifuging for $30 \mathrm{~min}$. at 40,000 r.p.m., therefore, the supernatant fluids were not poured off, but were carefully siphoned away leaving the bottom $0.5 \mathrm{ml}$. The pellet was extracted with this residual fluid plus $1.5 \mathrm{ml}$. of water, and after standing for an hour was centrifuged for a few minutes at $10,000 \mathrm{~g}$ to remove insoluble material.

Table 1 shows the results of one experiment in which similar lots of infected leaves from the same batch were treated in four different ways. Freezing the intact leaves before they were minced decreased the infectivity of the preparation without correspondingly decreasing its serological activity. By contrast, freezing the expressed sap had little effect on either of these specific properties, although sap stored at $3^{\circ}$ for $24 \mathrm{hr}$. had the greatest ratio of infectivity to serological activity - a result of the activation in sap already

Table 1. Effect of freezing on tobacco necrosis virus in sap and in intact leaves

\begin{tabular}{lccc}
\multicolumn{1}{c}{ and in intact leaves } & \multicolumn{2}{c}{$\begin{array}{c}\text { Infectivity } \\
\text { Mean lesions per half-leaf at }\end{array}$} \\
Treatment & $\overbrace{1 / 50}^{1 / 500}$ \\
Sap, 24 hr. at $3^{\circ}$ & $1 / 48$ & 86 & 22 \\
Sap, 24 hr. at $-10^{\circ}$ & $1 / 32$ & 85 & 14 \\
Intact leaves, $24 \mathrm{hr}$ at $3^{\circ}$ & $1 / 32$ & 84 & 11 \\
Intact leaves, 24 $\mathbf{~ h r}$ at $-10^{\circ}$ & $1 / 32$ & 18 & 1
\end{tabular}


described (Bawden \& Pirie, 1950). It was only when intact leaves were frozen that the ratio of infectivity to serological activity was decreased, and freezing minced leaves before pressing out the sap, like freezing the expressed sap, did not decrease it. The phenomenon occurs regularly when intact leaves are frozen, though the magnitude of the effect has varied somewhat with different lots of leaves. Durations of freezing between 3 and $48 \mathrm{hr}$. had no consistent effect, but the treatment of the leaves between freezing and mincing did influence the properties of the extractable material. Table 2 compares the

Table 2. Effect of freezing and washing intact leaves on ratio of serological activity and infectivity

\begin{tabular}{|c|c|c|c|c|}
\hline \multirow[b]{2}{*}{ Extract from } & \multirow[b]{2}{*}{ Precipitin titre } & \multicolumn{3}{|c|}{$\begin{array}{l}\text { Infectivity } \\
\text { Mean lesions per half-leaf at }\end{array}$} \\
\hline & & $1 / 20$ & $1 / 100$ & $1 / 500$ \\
\hline $\begin{array}{l}\text { Unfrozen leaves } \\
\text { Frozen leaves, thawed } \\
\text { before mincing }\end{array}$ & $\begin{array}{l}1 / 24 \\
1 / 8\end{array}$ & $\begin{array}{l}\mathbf{8 5} \\
\mathbf{2 8}\end{array}$ & $\begin{array}{r}48 \\
9\end{array}$ & $\begin{array}{r}24 \\
2\end{array}$ \\
\hline $\begin{array}{l}\text { Frozen leaves, washed } \\
\text { once before mincing }\end{array}$ & $1 / 8$ & 12 & 4 & 1 \\
\hline $\begin{array}{l}\text { Frozen leaves, washed } \\
\text { twice before mincing }\end{array}$ & $1 / 8$ & 6 & 1 & $\mathbf{0}$ \\
\hline
\end{tabular}

infectivity and serological activity of extracts from samples of one batch of leaves treated in different ways: unfrozen; frozen, thawed and minced without washing; and frozen and washed by stirring gently once or twice in twenty times their weight of distilled water. The diminution in infectivity caused by freezing is again obvious, and the decrease in the ratio of infectivity to serological activity was progressively increased by washing the leaves before mincing. As with tobacco mosaic virus (Bawden \& Pirie, 1945b), the washes contained little or no virus, whether this was assayed by infectivity tests or serologically. Freezing had not apparently anchored the infective virus to the leaf residue in such a way that it could be separated again by extraction with a suitable solvent. Many unsuccessful attempts were made to extract infective material from the leaf residues that remained after squeezing sap from minced leaves that had been frozen. Sap from uninfected tobacco leaves, the supernatant fluid from infective sap centrifuged at 40,000 r.p.m., the fluid that could be pressed from thawed unminced leaves, and various concentrations of sodium chloride and sodium phosphate, were all tried, but none extracted material with sufficient infectivity to account for that lost by freezing the intact leaves. The possibility that freezing extracted an inhibitor which accompanies the virus during one sedimentation was rendered unlikely by experiments in which virus from frozen and unfrozen leaves was further purified. One such comparison is shown in Table 3, from which it will be seen that, after three sedimentations, the material from frozen leaves had a rather greater serological activity than that from unfrozen leaves, but much less infectivity. Freezing either intact leaves or sap denatures many normal plant proteins and facilitates the preparation of the virus in the form in which it gives crystalline pellets and high serological titres. 
Table 3. The yields and relative activities of virus preparations made from

\begin{tabular}{lcccc} 
frozen and unfrozen leaves & \multicolumn{1}{c}{$\begin{array}{c}\text { Infectivity } \\
\text { Precipitation } \\
\text { Preparation }\end{array}$} & $\begin{array}{c}\text { Yield } \\
\text { end-point in } \\
\text { mg. } / 1 .\end{array}$ & $\overbrace{10 \mathrm{mg} . / \mathrm{l}}^{\text {Mean lesions per half-leaf at }}$ & $1 \mathrm{mg} . / \mathrm{l}$. \\
From frozen leaves & 170 & 12 & 11 & 1.5 \\
From unfrozen leaves & 200 & 18 & 42 & 6.5
\end{tabular}

Experiments comparable to those with frozen leaves were made by impairing the osmotic control of leaves by exposing them to chloroform or toluene, or by infiltrating water by repeatedly exposing immersed leaves to vacuum. In several experiments intact leaves were exposed to air saturated with chloroform for 1-3 days. The now limp and sodden leaves were then minced, the sap expressed and ultracentrifuged. The resulting extracts, like those from frozen leaves, were clearer than those from fresh leaves, and they sometimes gave a crystalline pellet on the first ultracentrifugation. Their properties have varied. Sometimes the material was much less infective than that sedimented from minced fresh leaves or from those kept intact for a comparable time without exposure to chloroform, but more often the total yield of virus was decreased and that extracted had about the same ratio of infectivity to serological activity as control pellets. The variations suggest that the treatments were causing protein destruction within the leaf cells and that the effect produced depended on the physiological condition of the leaves; we have made no attempt to control this more closely.

\section{Inactivation in vitro by citrate}

The readiness with which changes in the technique of preparation affect the infectivity of purified preparations of the Rothamsted tobacco necrosis virus (Bawden \& Pirie, 1950) suggested that the virus was sensitive to variations occurring in sap, particularly as previous work (Bawden \& Pirie, 1945a) had shown that exposure to moderate concentrations of sodium chloride and phosphate caused inactivation. We therefore studied the effect of several substances at concentrations within the range normal for leaves, in the hope of gaining information that might throw some light on the changes that proceed in infected leaves and sap. It soon became obvious that the extent of inactivation caused by different agents depended on so many variables that an extensive study of different agents was impossible, and we have restricted our experiments to the citrate ion. Even so, it has not yet proved possible so to define conditions that results are precisely reproducible after an interval. This may be because of changes continuously occurring in the purified virus preparations that affect their inactivation by citrate, and our experiments with preparations of different ages support this possibility. However, as every variable we have attempted to control has influenced the extent to which citrate inactivates, there are almost certainly others that do so and that we have not attempted to control. 
Fig. 1 shows the course of inactivation of two virus preparations at $18^{\circ}$ in $0.02 \mathrm{M}$ sodium citrate (pH 5.8). Equal volumes of $0.04 \mathrm{M}$ sodium citrate and $1.5 \mathrm{~g} . / \mathrm{l}$. virus were mixed at suitable times; all were diluted at the same time and compared for their infectivity with samples of the virus preparations to which citrate was added after dilution and immediately before inoculation to test plants. The final virus concentrations in the inocula were 5 and $0.5 \mathrm{mg} . / \mathrm{l}$.,

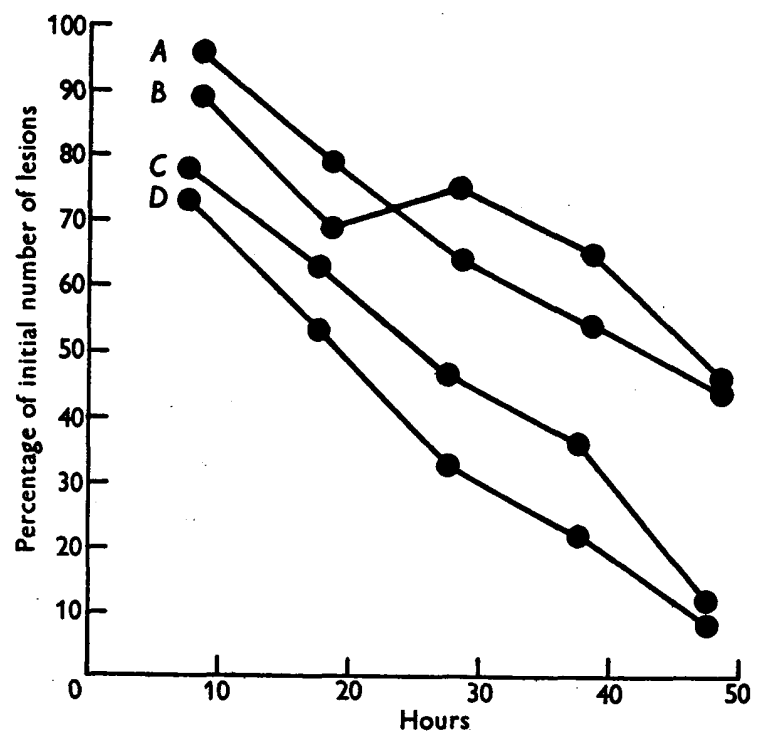

Fig. 1. Virus at $0.75 \mathrm{~g}$. $/$. was exposed to $0.02 \mathrm{M}$ citrate $\left(\mathrm{pH} 5 \cdot 8\right.$ ) at $18^{\circ}$ for various times and then tested on beans at two dilutions. The number of lesions after different periods of exposure is expressed as a percentage of the number given by a sample to which citrate was added after dilution and immediately before test; this number (mean per half-leaf) for each experiment was: $A$, freshly prepared virus tested at $5 \mathrm{mg} . / 1$., $126 ; B$, freshly prepared virus tested at $0.5 \mathrm{mg} . / 1 ., 45 ; C$, older virus tested at $5 \mathrm{mg} . / 1 ., 115 ; D$, older virus tested at $0.5 \mathrm{mg} . / 1 ., 39$.

and the results are recorded by expressing the numbers of lesions produced by the samples exposed to citrate for various lengths of time as percentages of the numbers produced by the relevant control, which was exposed only momentarily to citrate diluted $1 / 150$. When expressed in this manner, the course of inactivation in each of twelve similar experiments was substantially linear, but, as the numbers of lesions produced is not a simple function of the virus concentration, we regard this as fortuitous. It is clear that the freshly prepared virus from frozen sap was less affected than the older preparation; this difference was regularly observed, although it is not always as great as in the experiment set out in Fig. 1.

The rate at which infectivity is lost in the presence of citrate depends greatly on the temperature; an increase of $3^{\circ}$ in the range $15-22^{\circ}$ approximately halved the number of lesions produced when conditions were used which decreased the number of lesions given by samples exposed at $15^{\circ}$ to about one-quarter of that given by an unexposed control. In the $\mathrm{pH}$ range $6-7 \cdot 5$, the virus lost 
little infectivity over short periods either in the absence of buffer or in $0.02 \mathrm{M}$ glucosamine buffer, but small changes in $\mathbf{p H}$ affected inactivation by citrate. Table 4 records two experiments, showing that the rate of inactivation depends most closely on $\mathrm{pH}$ at about 6 , the value at which inactivation by $0 \cdot 1 \mathrm{M}$ phosphate is also most influenced by $\mathrm{pH}$ changes.

\section{Table 4. Effect of $\mathrm{pH}$ changes on inactivation by $0.02 \mathrm{M}$-citrate}

(Mixtures of virus at $1.4 \mathrm{~g}$./1. and citrate at the specified $\mathrm{pH}$ were kept for $24 \mathrm{hr}$. at $21^{\circ}$ before dilution and testing for infectivity.)

\begin{tabular}{|c|c|c|c|c|c|}
\hline \multicolumn{3}{|c|}{ Exp. 1} & \multicolumn{3}{|c|}{ Exp. 2} \\
\hline \multirow[b]{2}{*}{$\mathbf{p H}$} & \multicolumn{2}{|c|}{ Mean lesions per half-leaf at } & \multirow[b]{2}{*}{$\mathbf{p H}$} & \multicolumn{2}{|c|}{ Mean lesions per half-leaf at } \\
\hline & $5 \mathrm{mg} . / \mathrm{l}$. & $0.5 \mathrm{mg} . / 1$. & & $5 \mathrm{mg} . / 1$. & $0.5 \mathrm{mg} . / \mathrm{l}$. \\
\hline $\mathbf{5 \cdot 5}$ & 108 & $\mathbf{3 8}$ & $5 \cdot 6$ & 77 & 27 \\
\hline $6 \cdot 0$ & $\mathbf{5 2}$ & 14 & $5 \cdot 8$ & 60 & 13 \\
\hline $6 \cdot 5$ & 12 & $\mathbf{1}$ & $6 \cdot 0$ & 48 & 14 \\
\hline $7 \cdot 0$ & $7 \cdot 5$ & $0 \cdot 5$ & $\mathbf{6 \cdot 2}$ & $\mathbf{3 5}$ & $8 \cdot 5$ \\
\hline $5 \cdot 5^{*}$ & 132 & 41 & $5 \cdot 6^{*}$ & 80 & 22 \\
\hline $7 \cdot 0^{*}$ & 109 & 34 & $6 \cdot 2 *$ & 80 & $\mathbf{2 5}$ \\
\hline
\end{tabular}

In every experiment in which the concentration of citrate was varied between 0.05 and $0.003 \mathrm{M}$, a concentration was found which had maximum inactivating effect, and solutions both stronger and weaker inactivated less. This optimum concentration was not constant and varied, not only from virus preparation to preparation, but also with one preparation when tested again after an interval. Maximum inactivation usually occurred with a citrate concentration about $0.02 \mathrm{M}$, and, as the two experiments in Table 5 show, the

Table 5. Effect of concentration of citrate on extent of inactivation

(Mixtures of virus at $1.4 \mathrm{~g} . / 1$. and citrate or water were kept for $24 \mathrm{hr}$. at $21^{\circ}$ before dilution and testing for infectivity.)

\begin{tabular}{|c|c|c|c|c|c|}
\hline \multicolumn{3}{|c|}{ Exp, 1} & \multicolumn{3}{|c|}{ Exp. 2} \\
\hline \multirow[b]{2}{*}{$\begin{array}{l}\text { Molarity of } \\
\text { citrate }\end{array}$} & \multicolumn{2}{|c|}{$\begin{array}{c}\text { Mean lesions per } \\
\text { half-leaf at }\end{array}$} & \multirow[b]{2}{*}{$\begin{array}{l}\text { Molarity of } \\
\text { citrate }\end{array}$} & \multicolumn{2}{|c|}{$\begin{array}{c}\text { Mean lesions per } \\
\text { half-leaf at }\end{array}$} \\
\hline & $2 \mathrm{mg} . / 1$. & $\stackrel{0.2 \mathrm{mg} . / 1}{ }$ & & $2 \mathrm{mg} . / \mathrm{l}$. & $0.2 \mathrm{mg} \cdot / 1$ \\
\hline 0.04 & 42 & 5 & 0.05 & 100 & 48 \\
\hline 0.02 & 29 & 3 & 0.02 & 3 & $0 \cdot 2$ \\
\hline 0.01 & 8 & 2 & 0.008 & 27 & 8 \\
\hline $0 \cdot 005$ & 37 & 8 & $0 \cdot 0032$ & 175 & 74 \\
\hline 0.0025 & 91 & 13 & $0 \cdot 0$ & 177 & 100 \\
\hline 0.0 & 74 & 12 & & & \\
\hline
\end{tabular}

maximum can be well defined. The obvious interpretation of such a maximum is that the virus better resists the inactivating effect of citrate when the concentration of ions in the environment is increased. We therefore made many experiments in which the ionic concentration was increased by other salts. 
These have given very variable results, but Exp. 1 in Table 6 is typical of about one-half of those made. From this it is clear that both $0.02 \mathrm{M}$ sodium chloride and $0.02 \mathrm{M}$ calcium chloride caused little inactivation themselves and protected the virus from inactivation by citrate. That they do not invariably

Table 6. Effect of $\mathrm{NaCl}$ and $\mathrm{CaCl}_{2}$ on inactivation by citrate

(Virus at $0.6 \mathrm{~g}$./1. was incubated for $48 \mathrm{hr}$. at $\mathrm{pH} 5.8$ and $15^{\circ}$.)

\begin{tabular}{|c|c|c|c|c|c|}
\hline \multicolumn{3}{|c|}{ Exp. 1} & \multicolumn{3}{|l|}{ Exp. 2} \\
\hline & \multicolumn{2}{|c|}{$\begin{array}{l}\text { Mean lesions per } \\
\text { half-leaf at }\end{array}$} & \multirow[b]{2}{*}{ Solution used } & \multicolumn{2}{|c|}{$\begin{array}{c}\text { Mean lesions per } \\
\text { half-leaf at }\end{array}$} \\
\hline Solution used & \multicolumn{2}{|c|}{$2 \mathrm{mg} . / 1.0 .2 \mathrm{mg} . / \mathrm{l}$} & & \multicolumn{2}{|c|}{$2 \mathrm{mg} \cdot / 1.0 \cdot 2 \mathrm{mg} \cdot / 1$} \\
\hline $0.02 \mathrm{M}$ citrate & 24 & 2 & $0.08 \mathrm{M}$ citrate & 87 & 23 \\
\hline $0.02 \mathrm{~m}-\mathrm{NaCl}$ & 77 & 16 & $0.02 \mathrm{M}$ citrate & 8 & $\mathbf{1}$ \\
\hline $0 \cdot 02 \mathrm{M}-\mathrm{CaCl}_{2}$ & 74 & 13 & $0.02 \mathrm{M}$ citrate $+0.05 \mathrm{M}-\mathrm{NaCl}$ & 63 & 9 \\
\hline Citrate + $\mathrm{NaCl}$ & 66 & $\boldsymbol{9}$ & $0.008 \mathrm{M}$ citrate & 36 & $\mathbf{9}$ \\
\hline Citrate $+\mathrm{CaCl}_{2}$ & 75 & 16 & $0.008 \mathrm{M}$ citrate $+0.05 \mathrm{M}-\mathrm{NaCl}$ & $\mathbf{2}$ & $\mathbf{0}$ \\
\hline Water & 103 & 20 & Water & 113 & 24 \\
\hline
\end{tabular}

do so is partly explained by the results shown in Exp. 2 in Table 6, from which it seems that whereas $0.05 \mathrm{M}$ sodium chloride protected the virus from the inactivating effect of $0.02 \mathrm{M}$ citrate, it enhanced the effect of $0.008 \mathrm{M}$ citrate. Table 6 again shows an optimum concentration for inactivation. The inconstancy of the citrate concentration needed for maximum inactivation has already been mentioned; presumably this value affects the concentration of sodium chloride needed to inhibit or enhance the inactivating effect of citrate, and the interaction of these two factors, each of which has variable effects depending on concentration, seems sufficient to explain our often irregular results.

It is not only salts that seem to affect inactivation by citrate. Of the two antiseptics tried, the rate of inactivation by $0.02 \mathrm{M}$ citrate at $\mathrm{pH} 5.8$ and $18^{\circ}$ was slightly increased by the presence of saturated chloroform and was considerably retarded by saturation with thymol. Traces of chloroform were present in many of the experiments reported here, but thymol was not used as a disinfectant in any preparation destined for experiments with citrate.

A further variable that affects inactivation by citrate is the concentration of virus, and within the range we studied, inactivation was favoured by increased concentration. One experiment is shown in Table 7; virus at

Table 7. Effect of initial virus concentration on inactivation by citrate

\begin{tabular}{|c|c|}
\hline $\begin{array}{l}\text { Initial virus } \\
\text { concentration } \\
\text { (g./l.) }\end{array}$ & Treatment \\
\hline $0 \cdot 66$ & $\begin{array}{l}\text { Water } \\
0.02 \mathrm{M} \text { citrate } \\
0.02 \mathrm{M} \text { citrate added before testing }\end{array}$ \\
\hline 0.066 & $\begin{array}{l}\text { Water } \\
0.02 \mathrm{M} \text { citrate } \\
0.02 \mathrm{M} \text { citrate added before testing }\end{array}$ \\
\hline
\end{tabular}

(The fluids were kept for $48 \mathrm{hr}$. at $\mathrm{pH} 5.9$ and $16^{\circ}$.)

Mean lesions per half-leaf at

$\begin{array}{cc}2 \mathrm{mg} . / 1 . & 0 \cdot 2 \mathrm{mg} \cdot / \mathrm{l} . \\ 30 & 6 \cdot 5 \\ 12 & 2 \\ 40 & 5 \\ 39 & 5 \cdot 5 \\ 32 & 6 \\ 69 & 10 \\ & 32\end{array}$


$0.66 \mathrm{~g}$. $/ 1$. incubated for $48 \mathrm{hr}$. at $16^{\circ}$ produced only one-third of the number of lesions produced by the water control, whereas virus at $0.066 \mathrm{~g}$. $/ 1$. still produced almost as many lesions as did the water control. Table 7 also illustrates a phenomenon that we have frequently, though not invariably encountered; namely, that preparations exposed momentarily to citrate and the diluted, or mixed with diluted citrate, produced more lesions than corresponding water controls. The phenomenon complicates the interpretations of lesion counts so that comparisons with water controls may suggest less loss of infectivity than has actually occurred. The results from experiments in which the initial concentration of virus exposed to citrate was varied suggest that the rate of inactivation diminishes proportionally to the concentration of virus, which, at first sight, seems incompatible with the approximately linear relationship between time and percentage infectivity, which is illustrated in Fig. 1. However, there is no necessary incompatibility, for in none of the experiments is the relationship between lesion numbers and amounts of infective virus known; also, we do not know how the presence of variable quantities of non-infective particles affects the stability of infective particles towards citrate or influences the numbers of lesions produced by a given quantity of infective virus. The greater stability in dilute solutions is unusual with proteins, and is not found when this tobacco necrosis virus is exposed to agents other than citrate. The inactivation caused by neutral phosphate, for example, proceeds more rapidly in dilute than in concentrated virus solutions (Bawden \& Pirie, 1945a). To quote one experiment: when samples of the same preparation at concentrations of $2.0,0.5$ and $0.11 \mathrm{~g} . / 1$. were exposed to $0.1 \mathrm{M}$ phosphate at $\mathrm{pH} 6.6$ and $18^{\circ}$ for $7 \mathrm{hr}$., they gave respectively an average of 20,3 and 1 lesions per half-leaf at a dilution of $10 \mathrm{~g} . / 1$., whereas a control to which phosphate was added immediately before dilution gave 62 .

\section{DISCUSSION}

The results of our experiments on factors affecting the infectivity of the Rothamsted tobacco necrosis virus show how closely the effects of any given treatment depend on the immediate environment of the virus when the treatment is applied. In this paper we show that freezing infected leaves before they are minced to extract the virus leads to a product with much lower infectivity than if leaves are minced fresh. This contrasts vividly with the results recorded in the preceding paper (Bawden \& Pirie, 1950) on freezing infective sap; so far from decreasing infectivity, the initial freezing of the sap produces purified virus preparations with the highest infectivity per unit weight of dry matter that we have been able to prepare. No conclusive interpretation of these varied effects can be given, but various possibilities can be suggested. It may be that freezing in the leaves renders virus particles noninfective without affecting their serological activity, whereas something in expressed sap prevents this inactivation. This interpretation, however, does not fit well with the fact that the infectivity of extracts from frozen leaves is still further decreased when the leaves are washed with water before they are minced, for this suggests that some effect secondary to freezing is also in- 
fluencing infectivity. More in keeping with this phenomenon is the concept that the virus occurs in the leaf as a mixture of infective and non-infective particles, whose relative extractibility differs in fluids of different compositions. Another possibility is that freezing the leaves may combine the virus with some inhibitor of infectivity with which it is juxtaposed in intact cells but from which it is separated by mincing and extraction of sap. If this be so, the inhibitor must be firmly combined with the virus and remain with it through all stages of purification. In the experiments described in the preceding paper (Bawden \& Pirie, 1950) we show that this virus undergoes considerable increases in infectivity while lying in some kinds of plant sap, which suggests that some, at least, of the virus particles develop infectivity after the leaves have been macerated, perhaps because of contact with some activator or 'co-factor'. The interpretation that best fits all our results is that much of the virus in intact cells is non-infective and that freezing the leaves destroys, or causes to be lost from the leaves, materials that normally react with the virus to make it capable of initiating fresh infections.

The results of exposing purified preparations of this tobacco necrosis virus to citrate also show how greatly minor changes in the environment determine to what extent inactivation occurs. In this respect the Rothamsted tobacco necrosis virus is not unique, for the inactivation of potato virus $X$ (Bawden \& Crook, 1947) and of $T_{5}$ bacteriophage of Escherichia coli (Adams, 1949) by citrate and phosphate also depend on the presence of other substances. The inactivation of this tobacco necrosis virus by citrate and phosphate seems to differ from that of potato virus $X$, which loses not only infectivity but also all other characteristic properties when incubated with these ions. The serological activity of potato virus $\boldsymbol{X}$ is destroyed and it is denatured, the nucleic acid being split from the protein moiety. Preparations of the tobacco necrosis virus still retain their full serological activity after incubation with citrate or phosphate in conditions where all infectivity is destroyed. No precipitates of denatured protein separate from these preparations during the inactivation, and there is no evidence that nucleic acid is liberated; such non-infective preparations also still produce crystalline pellets when they are ultracentrifuged. Many agents are known that rob other viruses of their infectivity without affecting their physical or serological properties, and the action of citrate on the tobacco necrosis virus may be a further example of this phenomenon. However, with this tobacco necrosis virus, there is less evidence linking antigenicity and infectivity with one kind of particle than with other viruses that have been studied, and there is no proof that the serologically active crystallizable protein ever carries any infectivity. This material forms the bulk of purified preparations of the tobacco necrosis virus, and it may be that infective particles form only a minor part. If this be so, complete decomposition of the infective component would not necessarily lead to any detectable changes in the physical or serological properties of a preparation.

The experiments with citrate show that inactivation to various degrees can be expected in the conditions obtaining in plant sap. The sap from tobacco leaves, whether healthy or virus-infected, at the time when they are normally 
used for a virus preparation, contains $20-30 \mathrm{~g}$./l. of diffusible dry matter. The physiological state of the plant greatly influences both its amount and composition. No complete balance sheet of the components of this fluid has been made but a few figures can be given. Vickery \& Abrahams (1949) found that the citrate content can range from 0.04 to $0.20 \mathrm{M}$ according to the conditions of culture; they also found that there is usually more malic than citric acid in the leaf. We have found variable values for some other ions but 0.01, 0.02, 0.03 and $0.06 \mathrm{M}$ may be given as representative for $\mathrm{PO}_{4}, \mathrm{Ca}, \mathrm{Na}$ and $\mathrm{K}$ respectively. These figures fall in or near the range we have found to influence infectivity in vitro, so that it is possible that variations in the physiological state of the plant affect the severity of symptoms and the amount of virus in the leaf because of inactivations similar to those described here. Many other factors besides those we have mentioned may influence the activity, for we know nothing about the effects of leaf sugars and simple nitrogen compounds or of components with larger molecular-weight.

\section{REFERENCES}

ADAms, M. H. (1949). The stability of bacterial viruses in solutions of salts. J. gen. Physiol. 32, 579.

Bawden, F. C. \& Crook, E. M. (1947). Some properties of potato virus $X$ in leaf extracts made in different ways. Brit. J. exp. Path. 28, 403.

Bawden, F. C. \& Prrie, N. W. (1945a). Further studies on the purification and properties of a virus causing tobacco necrosis. Brit. J. exp. Path. 26, 277.

Bawden, F. C. \& Pirie, N. W. (1945b). The separation and properties of tobacco mosaic virus in different states of aggregation. Brit. J. exp. Path. 26, 294.

Bawden, F. C. \& PIRIE, N. W. (1950). Some factors affecting the activation of virus preparations made from tobacco leaves infected with a tobacco necrosis virus. J. gen. Microbiol. 4, 464.

Bawden, F. C. \& Roberts, F. M. (1947). The influence of light intensity on the susceptibility of plants to certain viruses. Ann. appl. Biol. 34, 286.

Bawden, F. C. \& Roberts, F. M. (1948). Photosynthesis and predisposition of plants to infection with certain viruses. Ann. appl. Biol. 35, 418.

Masker, A. V. (1941). A quantity type rotor for the ultracentrifuge. Rev. sci. Instrum. 12, 277.

Vrckery, H. B. \& Abrahams, M. D. (1949). The metabolism of the organic acids of tobacco leaves. II. Effect of culture of excised leaves in solutions of $D$-isocitrate and acetate. J. biol. Chem. 180, 37.

(Received 25 February 1950) 